\title{
Yield and nutritional composition of oyster mushroom strains newly introduced in Bangladesh
}

\author{
Mostak Ahmed(1), Noorlidah Abdullah(1), Kamal Uddin Ahmed(2) and M. H. M. Borhannuddin Bhuyan(3) \\ (1)University of Malaya, Faculty of Science, Institute of Biological Sciences, Mushroom Research Centre, 50603, Kuala Lumpur, Malaysia. \\ E-mail: mostaksau@gmail.com, noorlidah@um.edu.my (2)Sher-e-Bangla Agricultural University, Faculty of Agriculture, Department of \\ Biochemistry, Dhaka-1207, Bangladesh. E-mail: kuahmedsau18662@yahoo.com ${ }^{(3)}$ Bangladesh Agricultural Research Institute, Citrus \\ Research Station, Jaintiapur, Sylhet, Bangladesh. E-mail: razon_sau@yahoo.com
}

\begin{abstract}
The objective of this work was to evaluate yield and chemical composition of oyster mushroom strains newly introduced in Bangladesh. Strains of Pleurotus high-king (strain PHK), P. ostreatus (strain PO2), and $P$. geesteranus (strains PG1 and PG3) were evaluated as to yield components and proximate composition. Pleurotus ostreatus was used as control. Pleurotus high-king showed fastest growth of primordia, but moderate flush of effective fruiting bodies. Pleurotus geesteranus (PG1) showed higher economic yield and biological performance, and better chemical composition, especially in terms of protein and mineral contents. Pleurotus geesteranus (PG1) shows better performance than P. ostreatus (PO2), the most commercially cultivated edible species in Bangladesh, and, therefore, it should be recommended for commercial cultivation.

Index terms: Pleurotus, fruiting body, mushroom cultivation, proximate composition, yield components.

\section{Produtividade e composição nutricional de linhagens de cogumelo-ostra recentemente lançadas em Bangladesh}

\begin{abstract}
Resumo - O objetivo deste trabalho foi avaliar a produtividade e a composição química de linhagens de cogumelo-ostra introduzidas recentemente em Bangladesh. Linhagens de Pleurotus high-king (linhagem PHK), P. ostreatus (linhagem PO2) e P. geesteranus (linhagens PG1 e PG3) foram avaliadas quanto aos componentes da produção e à composição proximal. Pleurotus ostreatus foi utilizado como controle. Pleurotus high-king apresentou rápido crescimento de primórdios, mas fluxo moderado de corpos de frutificação efetivos. Pleurotus geesteranus (PG1) apresentou maior produtividade econômica e desempenho biológico, além de melhor composição química, especialmente em termos de conteúdos de proteína e minerais. Pleurotus geesteranus (PG1) apresenta melhor desempenho que P. ostreatus (linhagem PO2), a espécie comestível mais cultivada comercialmente em Bangladesh, e, portanto, deve ser recomendado para plantio comercial.
\end{abstract}

Termos para indexação: Pleurotus, corpo de frutificação, cultivo de cogumelos, composição proximal, componentes de produção.

\section{Introduction}

Oystermushrooms are a diverse group of saprotrophic fungi belonging to the genus Pleurotus (Kong, 2004). According to Croan (2004), these mushrooms are a good source of non-starchy carbohydrates, with high content of dietary fiber and moderate quantity of proteins, including most amino acids, minerals, and vitamins. The protein content varies from 1.6 to $2.5 \%$, and the niacin content is about ten times higher than that of any other vegetable. Moreover, Randive (2012) reported that oyster mushrooms are rich in Vitamin C, B complex, and mineral salts required by the human body.

Mushroom production in rural communities can alleviate poverty and improve the diversification of agricultural production (Godfrey et al., 2010). For successful cultivation, it is important to select high-yielding strains. However, the production and yield performance of commercial strains of mushrooms tend to decrease after consecutive subculturing (Naraian et al., 2011). Therefore, more information about this genus and its species is necessary to identify good strains to ensure continuous yield improvement (Uhart et al., 2008) and to screen the efficient varieties for Bangladesh.

Oyster mushroom can grow at moderate temperatures, ranging from 20 to $30^{\circ} \mathrm{C}$, and at a humidity of $55-70 \%$, on various agricultural waste materials used as substrate. Because of its flexible nature, the Pleurotus genus is more cultivated than 
any other mushroom species (Rosado et al., 2002). The climatic conditions and seasonal diversity of Bangladesh is ideal for the cultivation of the oyster mushroom (Amin et al., 2007b). The collection of the National Mushroom Development and Extension Centre (Namdec) in Bangladesh includes different strains of oyster mushrooms. In recent years, four new strains have been introduced: Pleurotus high-king (PHK), P. ostreatus (PO3), and P. geesteranus (PG1 and PG3). However, the performances of these strains have not yet been properly investigated in the climatic conditions of Bangladesh. Moreover, studies concerning the nutritive analysis of oyster mushrooms are not available in the country.

The objective of this work was to evaluate yield and chemical composition of oyster mushroom strains newly introduced in Bangladesh.

\section{Materials and Methods}

The experiment was carried out at the Biochemistry Laboratory and Mushroom Culture House (MCH) of the Department of Biochemistry of Sher-e-Bangla Agricultural University, Dhaka, Bangladesh. Pleurotus mycelia colonized packets, weighing $500 \mathrm{~g}$ each, obtained from Namdec, were used. The cultivation substrate consisted of wheat bran-supplemented sawdust in a polypropylene bag sealed with cotton wool and sterilized at $121^{\circ} \mathrm{C}$ for $20 \mathrm{~min}$. Mycelia culture of the four newly introduced oyster mushroom strains, namely $P$. high-king (PHK), P. ostreatus (PO3), P. geesteranus (PG1), P. geesteranus (PG2), and $P$. ostreatus (PO2), was inoculated separately. Pleurotus ostreatus (PO2) was used as the control, since it is the most commercially cultivated edible strain in Bangladesh.

For each evaluated Pleurotus strain, three replicate bags were prepared and incubated at five different plots in the $\mathrm{MCH}$, for full colonization of the substrate. Once fully colonized, induction of fruiting was done by cutting a " $D$ " shape with a sterilized blade at the opposite end, in the upper position of the culture bags. The cut plastic sheet was then removed. The opened surface was scraped slightly to remove the thin, whitish mycelial layer. Then, the culture bags were soaked in water for $15 \mathrm{~min}$ and inverted to remove excess water for another $15 \mathrm{~min}$. The packets of each mushroom species were placed separately, side-by-side, on the floor of the culture room and covered with newspaper. The moisture of the culture room was maintained at $80-85 \%$ relative humidity by spraying water three times per day. The room lighting was maintained at approximately 300-500 lx and ventilation was kept uniform. The temperature of the culture house was maintained between 22 and $25^{\circ} \mathrm{C}$.

The number of primordia (pinhead-like appearance) was counted and recorded. Oyster mushrooms achieved maturity within two to three days after primordia initiation. The matured fruiting body was identified by the curve margin of the cap, as described by Amin et al. (2007b). Mushrooms were harvested by twisting to uproot from the base.

Fully developed fruiting bodies were counted to determine the number of effective ones; tiny and deformed fruiting bodies were discarded at the time of counting. To obtain the average weight of individual fruiting bodies, the weight of each flush was taken and divided by the number of fruiting bodies. Average length, breadth, and thickness of three randomly selected pili (cap) were measured ( $\mathrm{mm}$ ) using slide calipers. The length and diameter of the stipe were also measured (mm). Mean fresh weight of the three consequent flushes of each bag was calculated for total yield (g per $500 \mathrm{~g}$ per bag). Fruiting bodies were collected as cluster form from spawn bags. The whole cluster of fruiting bodies was considered for biological yield measurement, and the cleaned fruiting bodies (separated from cluster by removing lower tough and dirty portion) were weighted to obtain economic yield (Sarker et al., 2007b). The conversion percentage (biological efficiency) was determined (Pathmashini et al., 2008) as follows: biological efficiency (BE) = (grams of fresh weight of mushroom/dry weight of substrate) $\times 100$.

After harvesting of the first flush, packets were scraped again in the position where the "D" shaped cut was made. The packets were soaked in a bucket for $15 \mathrm{~min}$, inverted for another $15 \mathrm{~min}$ to remove excess water, and placed in the culture house. This practice was repeated after each flush. Water was sprayed regularly to maintain humidity (80-85\%). Three flushes of each packet were harvested and recorded.

Fruiting bodies of all five oyster mushroom strains were analyzed for nutritional composition according to the Association of Official Analytical Chemists (Cunnif, 1995). The contents of moisture, 
dry matter, protein, lipid, ash, carbohydrate, crude fiber, and minerals were determined. The evaluated minerals included nitrogen, calcium, magnesium, potassium, phosphorus, copper, zinc, manganese, and iron. Values for $\mathrm{N}$ were determined using the micro Kjeldahl apparatus; $\mathrm{P}$ values were calculated by a spectrophotometer; $\mathrm{Ca}, \mathrm{Mg}, \mathrm{Cu}, \mathrm{Mn}, \mathrm{Fe}$, and $\mathrm{Zn}$ values were obtained using an atomic absorption spectrophotometer; and $\mathrm{K}$ values were determined by a flame photometer after standardizing against respective elements (Cuniff, 1995). The fractions $(\%)$ of protein, fat, crude fiber, and ash were added together and subtracted from 100 to obtain the total carbohydrate percentage, whereas the dry weight of nitrogen and fat free extract were calculated as the percentage of crude fiber.

The data were statistically analyzed using the MSTAT-C computer package program (Michigan State University, East Lansing, MI, USA). Analysis of variance was conducted and means were compared using the least significant difference (LSD) test, at 1 and 5\% probability (Gomez \& Gomez, 1984).

\section{Results and Discussion}

All the Pleurotus strains produced first primordia seven to ten days after scraping (primordia induction) (Table 1). Primordia emergence was fastest in P. high-king and P. ostreatus (PO2). Both strains of $P$. geesteranus (PG1 and PG3) exhibited slowest primordia emergence. Obodai et al. (2003) reported that pinhead formation took four to six days after the completion of spawn running, with harvest after 10 to 12 days in the case of $P$. ostreatus on different substrate, in the climatic conditions of Pakistan. Strain PHK also produced the highest number of primordia, followed by strains PG1 and PG3, whereas the lowest number of primordia per $500 \mathrm{~g}$ per bag was produced by PO2 and PO3. Islam et al. (2009) and Monadal et al. (2010) also found a significant number of primordia on P. florida (134.25 in sawdust) and P. flabellatus (44 in mango sawdust), evaluated on different substrates in Bangladesh. If the number of primordia increases, fruiting body formation and weight of fruiting body are compromised, and yield is ultimately reduced (Sarker et al., 2007b).

Strain PHK produced the highest number of mature fruiting bodies, followed by strain PO3, whereas strain PG3 had the lowest value, similar to strain PG1 (Table 1). Although strain PHK was attractive in terms of appearance time of primordia, number of primordia, and effective number of fruiting bodies, it did not show good performance for individual weight of fruiting body. Among the tested species, the average weight of single fruiting body produced by PG1 was the heaviest, followed by strain PG3 (Table 1). Sarker et al. (2007b) observed that the weight of single fruiting body of oyster mushrooms ranged between $1.33-1.59 \mathrm{~g}$, lower than that obtained in the present study, which ranged from 2.42 to $7.42 \mathrm{~g}$. These new strains may be more suitable to the climatic conditions of Bangladesh, forming heavier fruiting bodies. Uddin et al. (2011) reported that the environmental condition of Bangladesh (average minimum and maximum temperature of 14 to $35^{\circ} \mathrm{C}$; relative humidity of $70-80 \%)$ is suitable for the cultivation of oyster mushroom.

The largest diameter of the pileus was found in strain PG3 (Table 2), which was similar to the control (Table 2), and the smallest was recorded for strains PHK, PO3, and PG1, which showed similar results, in accordance with Monadal et al. (2010) findings. The size of the stalk and pileus is positively correlated to yield and to carbohydrate and protein

Table 1. Emergence and number of primordia, number and weight of fully developed fruiting bodies, total yield, and biological efficiency of newly introduced Pleurotus strains ${ }^{(1)}$.

\begin{tabular}{cccccc}
\hline Variable & \multicolumn{5}{c}{ Pleurotus strains $^{(2)}$} \\
\cline { 2 - 6 } & PHK & PO3 & PG1 & PG3 & PO2 \\
\hline Primordia & & & & \\
IT (days) & $7.6 \pm 0.2 \mathrm{~b}$ & $8.0 \pm 0.3 \mathrm{~b}$ & $9.8 \pm 0.4 \mathrm{a}$ & $10.2 \pm 0.4 \mathrm{a}$ & $7.6 \pm 0.2 \mathrm{~b}$ \\
Number & $197.8 \pm 1.7 \mathrm{a}$ & $84.4 \pm 1.8 \mathrm{~b}$ & $191.6 \pm 4.3 \mathrm{a}$ & $184.6 \pm 6.4 \mathrm{a}$ & $71.4 \pm 1.2 \mathrm{~b}$ \\
Fruinting & & \multicolumn{5}{c}{} & \\
Number & $60.4 \pm 2.1 \mathrm{a}$ & $49.4 \pm 2.3 \mathrm{~b}$ & $30.4 \pm 0.8 \mathrm{~cd}$ & $25.0 \pm 0.5 \mathrm{~d}$ & $34.6 \pm 0.5 \mathrm{c}$ \\
Weight (g) & $2.4 \pm 0.1 \mathrm{~d}$ & $2.8 \pm 0.0 \mathrm{~cd}$ & $7.4 \pm 0.3 \mathrm{a}$ & $5.6 \pm 0.3 \mathrm{~b}$ & $3.4 \pm 0.0 \mathrm{c}$ \\
Total yield & & & & & \\
Biological & $178.6 \pm 2.6 \mathrm{c}$ & $163.8 \pm 1.6 \mathrm{~d}$ & $278.0 \pm 3.7 \mathrm{a}$ & $188.5 \pm 1.0 \mathrm{~b}$ & $171.4 \pm 2.5 \mathrm{~cd}$ \\
Economic $^{(175.7 \pm 2.7 \mathrm{~b}}$ & $157.8 \pm 1.5 \mathrm{c}$ & $273.6 \pm 3.8 \mathrm{a}$ & $185.2 \pm 0.7 \mathrm{~b}$ & $163.2 \pm 2.9 \mathrm{c}$ \\
BE $^{(4)}(\%)$ & $61.5 \pm 0.9 \mathrm{c}$ & $56.4 \pm 0.5 \mathrm{~d}$ & $95.8 \pm 1.3 \mathrm{a}$ & $65.0 \pm 0.4 \mathrm{~b}$ & $59.1 \pm 0.9 \mathrm{~cd}$ \\
\hline
\end{tabular}

${ }^{(1)}$ Means \pm standard error followed by equal letters do not differ significantly at $1 \%$ probability. ${ }^{(2)} \mathrm{PHK}$, P. high-king; PO3, P. ostreatus; PG1, P. geesteranus; PG3, P. geesteranus; PO2, P. ostreatus. ${ }^{(3)}$ Biological yield (g per bag), the whole cluster of fruiting bodies; economic yield ( $\mathrm{g}$ per bag), cleaned fruiting bodies separated from cluster and dirty portion. ${ }^{(4)} \mathrm{BE}$, biological efficiency: fresh weight of mushroom $(\mathrm{g})$ per dry weight of substrate $(\mathrm{g})$ $\times 100$ (Pathmashini et al., 2008). 
contents, respectively (Ajonina et al., 2012). These authors observed differences in stalk length (2.43 to $3.24 \mathrm{~cm}$ ) for P. ostreatus, whereas Monadal et al. (2010) reported a decrease in the storage quality of the oyster mushroom with the increase of the pileus and stalk diameters. In the present study, the quality of the fruiting body was not considered. However, in the case of yield, the larger the pileus size, the higher the yield.

Thickness and diameter of the pileus influence fruiting body weight. The fruiting body of the control strain PO2 was thickest in comparison with the other studied strains. Thicknesses recorded ranged from 5.2 to $8.2 \mathrm{~mm}$. Strain PHK showed the thinnest pileus, followed by strains PO3 and PG1. Sarker et al. (2007b) found an average thickness of pileus of 5.0 to $8.0 \mathrm{~mm}$ for oyster mushroom.

The highest biological yield was obtained for strain PG1, which was significantly higher than other treatments (Table 1). Pathmashini et al. (2008) recorded $276.87 \mathrm{~g}$ as the highest biological yield for strain PO2 in sawdust with kurakkan spawn.

Strain PG1 also had the highest economic yield, followed by strains PG3 and PHK. Maximum biological efficiency was exhibited by strain PG1, followed by strain PG3, whereas PO2 had the lowest performance, similar to PO3. Amin et al. (2007a) and Sarker et al. (2007b) found similar yield for P. ostreatus. However, Obodai et al. (2003) reported a biological efficiency ranging from 61 to $0 \%$ for $P$. ostreatus. This could be due to the different substrate formulations and strain variations.

The calculated percentage of moisture and dry matter of the fruiting body ranged from 86.20 to 90.00 and from 10.00 to 13.80 , respectively (Table 3 ). Strain PO3 contained the highest moisture, similar

Table 2. Dimensions of yield contributing characters of newly introduced Pleurotus strains ${ }^{(1)}$.

\begin{tabular}{lccccc}
\hline Dimen- & \multicolumn{5}{c}{ Pleurotus strains $^{(3)}$} \\
\cline { 2 - 6 } sions $^{(2)}$ & PHK & PO3 & PG1 & PG3 & PO2 \\
\hline DS (mm) & $5.8 \pm 0.2 \mathrm{~b}$ & $5.8 \pm 0.3 \mathrm{~b}$ & $6.4 \pm 0.4 \mathrm{~b}$ & $7.6 \pm 0.2 \mathrm{a}$ & $7.4 \pm 0.3 \mathrm{a}$ \\
DP (mm) & $49.8 \pm 1.8 \mathrm{c}$ & $51.4 \pm 0.7 \mathrm{bc}$ & $61.4 \pm 0.8 \mathrm{bc}$ & $89.6 \pm 8.9 \mathrm{a}$ & $68.0 \pm 1.6 \mathrm{~b}$ \\
SL (mm) & $55.1 \pm 2.0 \mathrm{c}$ & $31.2 \pm 1.1 \mathrm{~d}$ & $98.0 \pm 2.3 \mathrm{a}$ & $82.4 \pm 0.2 \mathrm{~b}$ & $27.1 \pm 1.7 \mathrm{~d}$ \\
PT (mm) & $5.2 \pm 0.2 \mathrm{c}$ & $5.6 \pm 0.3 \mathrm{bc}$ & $6.0 \pm 0.0 \mathrm{bc}$ & $6.4 \pm 0.2 \mathrm{~b}$ & $8.2 \pm 0.3 \mathrm{a}$ \\
\hline
\end{tabular}

${ }^{(1)}$ Means \pm standard error followed by equal letters do not differ significantly at $1 \%$ probability. ${ }^{(2)} \mathrm{DS}$, diameter stalk; DP, diameter pileus; SL, stalk length; PT, pileus thickness. ${ }^{(3)} \mathrm{PHK}$, P. high-king; PO3, P. ostreatus; PG1, P. geesteranus; PG3, P. geesteranus; PO2, P. ostreatus (control). to strains PHK and PO2. Alam et al. (2007) reported 87-87.5\% moisture for existing Pleurotus spp. in Bangladesh. This was especially the case for P. florida and $P$. sajor-caju. Moisture percentage in mushroom depends on the species, maturity of fruiting bodies, and storage conditions during processing or packaging (Guillamón et al., 2010).

Pleurotus spp. are considered good source of superior quality protein, with well distributed essential amino acids (Patil et al., 2010). In this experiment, the highest protein content was found in strain PG1, and the remaining treatments were statistically similar (Table 3). Chang et al. (1981) reported that the fruiting bodies of mushrooms contain 26.6-34.1\% crude protein. Strain PO2 had the highest lipid content, followed by strain PHK, whereas strain PG3 contained the lowest amount of lipid, similarly to PG1. Alam et al. (2007) found similar data (4.30 to $4.41 \%$ ) while evaluating P. florida and P. sajor-caju. Strain PG1 contained the highest ash percentage, followed by strains PHK and PO3, which is in agreement with Khlood et al. (2005). All strains differed significantly from the control strain $\mathrm{PO} 2$ as to percentage of carbohydrate content (Table 3). This result differed from that obtained by Chang et al. (1981), but is supported by the findings of Alam et al. (2007). The maximum and minimum levels of crude fiber were recorded in strains PO3 and PO2, respectively. Alam et al. (2007) obtained 24.34\% fiber (in dry weight basis) when studying P. ostreatus. The strains examined in the present study showed a low-fat level, as well as a high amount of protein and fiber. Strain PG1 performed better when compared with the control strain $\mathrm{PO} 2$ as to protein, fat, ash, and fiber contents.

Mineral content is also important for the nutritional value of mushrooms. The species provides a reasonable amount of minerals in comparison with vegetables (Guillamón et al., 2010). The evaluated strains differed in mineral content. Strain PG1 contained the highest percentage of nitrogen; strain PG3 of potassium, calcium, and magnesium; strain PO2 of phosphorus. As to the other characters, the strains were statistically similar (Table 4). These results are in accordance with Chang et al. (1981) and Alam et al. (2007), but differ from Sarker et al. (2007a) who found 0.97\% phosphorus in oyster mushrooms grown on sawdust based substrates. 
Table 3. Moisture, dry matter, and chemical composition of newly introduced Pleurotus strains ${ }^{(1)}$.

\begin{tabular}{|c|c|c|c|c|c|}
\hline \multirow[t]{2}{*}{ Variable } & \multicolumn{5}{|c|}{ Pleurotus strains ${ }^{(2)}$} \\
\hline & PHK & $\mathrm{PO} 3$ & PG1 & PG3 & $\mathrm{PO} 2$ \\
\hline Moisture & $87.8 \pm 0.6 \mathrm{ab}$ & $90.0 \pm 0.3 \mathrm{a}$ & $86.2 \pm 0.7 b$ & $86.6 \pm 0.8 b$ & $89.4 \pm 1.0 \mathrm{ab}$ \\
\hline Dry matter & $12.2 \pm 0.6 \mathrm{ab}$ & $10.0 \pm 0.3 \mathrm{~b}$ & $13.8 \pm 0.7 \mathrm{a}$ & $13.4 \pm 0.8 \mathrm{a}$ & $10.6 \pm 1.0 \mathrm{ab}$ \\
\hline Protein $^{(3)}$ & $28.0 \pm 0.3 b$ & $28.4 \pm 0.4 b$ & $31.8 \pm 0.6 \mathrm{a}$ & $28.8 \pm 0.7 b$ & $28.4 \pm 1.0 \mathrm{~b}$ \\
\hline $\operatorname{Lipid}^{(3)}$ & $4.1 \pm 0.1 b$ & $3.8 \pm 0.0 \mathrm{c}$ & $3.6 \pm 0.1 \mathrm{~cd}$ & $3.5 \pm 0.1 \mathrm{~d}$ & $4.7 \pm 0.1 \mathrm{a}$ \\
\hline $\operatorname{Ash}^{(3)}$ & $11.5 \pm 0.5 b$ & $11.4 \pm 0.4 \mathrm{~b}$ & $12.8 \pm 0.4 \mathrm{a}$ & $11.2 \pm 0.2 \mathrm{c}$ & $8.6 \pm 0.3 \mathrm{~d}$ \\
\hline $\mathrm{CHO}^{(3,4)}$ & $29.2 \pm 0.4 d$ & $29.6 \pm 0.4 d$ & $33.4 \pm 0.5 b$ & $31.6 \pm 0.2 \mathrm{c}$ & $35.4 \pm 0.3 \mathrm{a}$ \\
\hline Crude fiber ${ }^{(3)}$ & $23.6 \pm 0.5 b$ & $27.4 \pm 0.5 \mathrm{a}$ & $22.6 \pm 0.5 \mathrm{c}$ & $23.0 \pm 0.7 \mathrm{~b}$ & $21.8 \pm 0.4 \mathrm{~d}$ \\
\hline
\end{tabular}

${ }^{(1)}$ Means \pm standard error followed by equal letters do not differ significantly at $1 \%$ probability. ${ }^{(2)} \mathrm{PHK}, P$. high-king; PO3, P. ostreatus; PG1, P. geesteranus; PG3, P. geesteranus; PO2, P. ostreatus (control). ${ }^{(3)}$ Determined on dry matter basis. ${ }^{(4)}$ Carbohydrate.

Table 4. Nutrient content of newly introduced Pleurotus strains $^{(1)}$.

\begin{tabular}{lccccc}
\hline Nutrient & \multicolumn{5}{c}{ Pleurotus strains ${ }^{(2)}$} \\
\cline { 2 - 6 } & PHK & PO3 & PG1 & PG3 & PO2 \\
\hline $\mathrm{N}\left(\mathrm{g} \mathrm{kg}^{-1}\right)$ & $45 \pm 0 \mathrm{~b}$ & $45 \pm 1 \mathrm{~b}$ & $49 \pm 2 \mathrm{a}$ & $46 \pm 1 \mathrm{~b}$ & $45 \pm 1 \mathrm{~b}$ \\
$\mathrm{P}\left(\mathrm{g} \mathrm{kg}^{-1}\right)$ & $8 \pm 0 \mathrm{~b}$ & $8 \pm 0 \mathrm{~b}$ & $8 \pm 0 \mathrm{~b}$ & $8 \pm 0 \mathrm{~b}$ & $9 \pm 0 \mathrm{a}$ \\
$\mathrm{K}\left(\mathrm{g} \mathrm{kg}^{-1}\right)$ & $12 \pm 0 \mathrm{c}$ & $13 \pm 0 \mathrm{~b}$ & $13 \pm 0 \mathrm{~b}$ & $14 \pm 0 \mathrm{a}$ & $13 \pm 0 \mathrm{~b}$ \\
$\mathrm{Ca}\left(\mathrm{g} \mathrm{kg}^{-1}\right)$ & $304 \pm 1 \mathrm{~d}$ & $322 \pm 1 \mathrm{bc}$ & $316 \pm 1 \mathrm{c}$ & $338 \pm 1 \mathrm{a}$ & $327 \pm 4 \mathrm{~b}$ \\
$\mathrm{Mg}\left(\mathrm{g} \mathrm{kg}^{-1}\right)$ & $105 \pm 0 \mathrm{c}$ & $106 \pm 1 \mathrm{c}$ & $116 \pm 2 \mathrm{~b}$ & $122 \pm 2 \mathrm{a}$ & $119 \pm 2 \mathrm{ab}$ \\
$\mathrm{Fe}\left(\mathrm{g} \mathrm{kg}^{-1}\right)$ & $468 \pm 11 \mathrm{a}$ & $468 \pm 5 \mathrm{a}$ & $431 \pm 7 \mathrm{bc}$ & $456 \pm 8 \mathrm{ab}$ & $421 \pm 4 \mathrm{c}$ \\
$\mathrm{Cu}\left(\mathrm{mg} \mathrm{kg}^{-1}\right)$ & $3.6 \pm 0.0 \mathrm{a}$ & $3.5 \pm 0.0 \mathrm{a}$ & $3.5 \pm 0.0 \mathrm{a}$ & $3.4 \pm 0.1 \mathrm{a}$ & $3.2 \pm 0.1 \mathrm{~b}$ \\
$\mathrm{Mn}\left(\mathrm{mg} \mathrm{kg}^{-1}\right)$ & $2.6 \pm 0.1 \mathrm{a}$ & $2.4 \pm 0.0 \mathrm{ab}$ & $2.3 \pm 0.1 \mathrm{~b}$ & $2.6 \pm 0.0 \mathrm{a}$ & $2.5 \pm 0.1 \mathrm{ab}$ \\
$\mathrm{Zn}\left(\mathrm{mg} \mathrm{kg}^{-1}\right)$ & $12.5 \pm 0.0 \mathrm{c}$ & $12.9 \pm 0.0 \mathrm{~b}$ & $12.5 \pm 0.0 \mathrm{c}$ & $12.9 \pm 0.0 \mathrm{~b}$ & $13.3 \pm 0.2 \mathrm{a}$ \\
\hline
\end{tabular}

${ }^{(1)}$ Means \pm standard error followed by equal letters do not differ significantly at $1 \%$ probability. ${ }^{(2)} \mathrm{PHK}$, P. high-king; PO3, P. ostreatus; PG1, P. geesteranus; PG3, P. geesteranus; PO2, P. ostreatus (control).

\section{Conclusions}

1. Pleurotus geesteranus, strain PG1, has the highest yield and biological efficiency, superior to Pleurotus ostreatus, the most commercially cultivated edible strain in Bangladesh.

2. Pleurotus strains vary in chemical composition and nutritional value, and Pleurotus geesteranus, strain PG1, presents higher contents of protein, ash, and $\mathrm{Cu}$, as well as reduced contents of lipid and carbohydrate when compared to Pleurotus ostreatus.

\section{Acknowledgements}

To the Mushroom Research Center of the Institute of Biological Sciences, Faculty of Science, University of Malaya, Malaysia; to the Sher-e-Bangla Agricultural University, Dhaka, Bangladesh; and to the National
Mushroom Development and Extension Centre (Namdec), Dhaka, Bangladesh, for support.

\section{References}

AJONINA, A.S.; TATAH, L.E. Growth performance and yield of oyster mushroom (Pleurotus ostreatus) on different substrates composition in Buea South West Cameroon. Science Journal of Biochemistry, v.2012, p.1-6, 2012. DOI: 10.7237/sjbch/139.

ALAM, N.; KHAN, A.; HOSSAIN, M.S.; AMIN, S.M.R.; KHAN, L.A. Nutritional analysis of dietary mushroom Pleurotus florida Eger and Pleurotus sajor-caju (Fr.) Singer. Bangladesh Journal of Mushroom, v.1, p.1-7, 2007.

AMIN, S.M.R.; RAHMAN, M.M.; HOSSAIN, M.M.; HAQUE, M.M.; SARKER, N.C. Effect of different substrates on the growth and yield of five selected oyster mushrooms. Bangladesh Journal of Mushroom, v.1, p.21-25, 2007a.

AMIN, S.M.R.; SARKER, N.C.; KHAIR, A.; ALAM, N. Detection of novel supplements of paddy straw substrate on oyster mushroom cultivation. Bangladesh Journal of Mushroom, v.1, p.33-37, 2007b.

CHANG, S.T.; LAU, O.W.; CHO, K.Y. The cultivation and nutritional value of Pleurotus sajor-caju. European Journal of Applied Microbiology and Biotechnology, v.12, p.58-62, 1981. DOI: $10.1007 / \mathrm{BF} 00508120$.

CROAN, S.C. Conversion of conifer wastes into edible and medicinal mushrooms. Forest Products Journal, v.54, p.68-76, 2004.

CUNIFF, P. (Ed.). Official methods of analysis of AOAC International. $16^{\text {th }}$ ed. Gaithersburg: AOAC International, 1995. $2 \mathrm{v}$.

GODFREY, E.Z.; SITI, M.K.; JUDITH, Z.P. Effects of temperature and hydrogen peroxide on mycelial growth of eight Pleurotus strains. Scientia Horticulture, v.125, p.95-102, 2010. DOI: 10.1016/j.scienta.2010.03.006.

GOMEZ, K.A.; GOMEZ, A.A. Statistical procedures for agricultural research. $2^{\text {nd }}$ ed. New York: John Wiley and Sons, 1984.

GUILLAMÓN, E.; GARCÍA-LAFUENTE, A.; LOZANO, M.; D' ARRIGO, M.; ROSTAGNO, M.A.; VILLARES, A.; MARTÍNEZ, J.A. Edible mushrooms: role in the prevention of cardiovascular diseases. Fitoterapia, v.81, p.715-723, 2010. DOI: 10.1016/j. fitote.2010.06.005

ISLAM, M.Z.; RAHMAN, M.H.; HAFIZ, F. Cultivation of oyster mushroom (Pleurotus flabellatus) on different substrate. International Journal of Sustainable Crop Production, v.4, p.45-48, 2009.

KHLOOD, A.; AHMAD, A. Production of oyster mushroom (Pleurotus ostreatus) on olive cake agro waste. Dirasat, Agricultural Science, v.32, p.64-70, 2005.

KONG, W.-S. Descriptions of commercially important Pleurotus species. In: Mushroom world (Ed.). Oyster mushroom cultivation. Part II. Oyster mushrooms. Seoul: Heineart Incorporation, 2004. p.54-61. (Mushroom growers' handbook, 1). 
MONADAL, S.R.; REHANA, M.J.; NOMAN, S.M.; ADHIKARY, S.K. Comparative study on growth and yield performance evaluation of oyster mushroom (Pleurotus florida) on different substrates. Journal of the Bangladesh Agricultural University, v.8, p.213-220, 2010.

NARAIAN, R.; JATIN, S.; SATYENDRA, K.G. Influence of dairy spent wash (DSW) on different cultivation phases and yield response of two Pleurotus mushrooms. Annals of Microbiology, v.61, p.853-862, 2011. DOI: 10.1007/s13213-011-0206-9.

OBODAI, M.; CLELAND-OKINE, J.; VOWOTOR, K.A. Comparative study on the growth and yield of Pleurotus ostreatus mushroom on different lignocellulosic by-products. Journal of Industrial Microbiology and Biotechnology, v.30, p.146-149, 2003. DOI: 10.1007/s10295-002-0021-1.

PATHMASHINI, L.; ARULNANDHY, V.; WIJERATNAM, R.S.W. Cultivation of oyster mushroom (Pleurotus ostreatus) on sawdust. Ceylon Journal of Science (Biological Science), v.37, p.177-182, 2008. DOI: 10.4038/cjsbs.v37i2.505.

PATIL, S.S.; AHMED, S.A.; TELANG, S.M.; BAIG, M.M.V. The nutritional value of Pleurotus ostreatus (Jacq. Fr) Kumm cultivated on different lignocellulosic agro-wastes. Innovative Romanian Food Biotechnology, v.7, p.66-76, 2010.

RANDIVE, S.D. Cultivation and study of growth of oyster mushroom on different agricultural waste substrate and its nutrient analysis. Advances in Applied Science Research, v.3, p.1938-1949, 2012.
ROSADO, F.R.; CARBONERO, E.R.; KEMMELMEIER, C.; TISCHER, C.A.; GORIN, P.A.J.; IACOMINI, M. A partially 3-0-methylated $(1 \rightarrow 4)$ linked $\alpha$-d-galactan and $\alpha$-d-mannan from Pleurotus ostreatoroseus Sing. FEMS Microbiology Letter, v.212, p.261-265, 2002. DOI: 10.1111/j.1574-6968.2002. tb11276.x.

SARKER, N.C.; HOSSAIN, M.M.; SULTANA, N.; MIAN, I.H.; KARIM, A.J.M.S.; AMIN, S.M.R. Impact of different substrates on nutrient content of Pleurotus ostreatus (Jacquin ex Fr.) Kummer. Bangladesh Journal of Mushroom, v.1, p.51-56, 2007a.

SARKER, N.C.; HOSSAIN, M.M.; SULTANA, N.; MIAN, I.H.; KARIM, A.J.M.S.; AMIN, S.M.R. Performance of different substrates on the growth and yield of Pleurotus ostreatus (Jacquin ex Fr.) Kummer. Bangladesh Journal of Mushroom, v.1, p.9-20, 2007b.

UDDIN, M.N.; YESMIN, S.; KHAN, M.A.; TANIA, M.; MOONMOON, M.; AHMED, S. Production of oyster mushrooms in different seasonal conditions of Bangladesh. Journal of Scientific Research, v.3, p.161-167, 2011. DOI: 10.3329/jsr. v3i1.6130.

UHART, M.; PISCERA, J.M.; ALBERTÓ, E. Utilization of new naturally occurring strains and supplementation to improve the biological efficiency of the edible mushroom Agrocybe cylindracea. Journal of Industrial Microbiology and Biotechnology, v.35, p.595-602, 2008. DOI: 10.1007/ s10295-008-0321-1.

$\overline{\text { Received on July 15, } 2012 \text { and accepted on January 30, } 2013}$ 